\title{
Computational Thinking in K-12 Schools Using Hands-on Activities
}

\section{Dr. Nikunja Swain P.E., South Carolina State University}

Dr. Swain is currently a professor at the South Carolina State University. Dr. Swain has 25+ years of experience as an engineer and educator. He has more than 50 publications in journals and conference proceedings, has procured research and development grants from the NSF, NASA, DOT, DOD, and DOE and reviewed number of books on computer related areas. He is also a reviewer for ACM Computing Reviews, IJAMT, CIT, ASEE, and other conferences and journals. He is a registered Professional Engineer in South Carolina and ETAC of ABET reviewer for Electrical Engineering Technology and Computer Engineering Technology.

\section{Ms. Wanda Moses, South Carolina State University}

Wanda Moses is a Computer Science Instructor at South Carolina State University and a Ph.D. candidate in Computer Science at Clemson University in Clemson, SC. She's in the Human-Centered Computing Lab under the advisement of Dr. Juan E. Gilbert. Moses is a native of North Charleston, SC. She received her bachelor's degree in Mathematics and Computer Science from South Carolina State University in Orangeburg and her master's degree in Computer Science and Software Engineering from Auburn University in Auburn, AL. Her research interests include finding ways to use technology to assist minority women in making healthy lifestyle choices. She enjoys reading, traveling, attending cultural events and talking with elderly people.

\section{Dr. James Allen Anderson, South Carolina State University Ms. Cynthia T Davis, SC State University}

Cynthia Davis earned her B.S. in Mathematics Education in 1979 from Benedict College at Columbia, South Carolina, and her M.S. in Computer Science in 1982 from Atlanta University at Atlanta, Ga. From 1992 to 1996, Davis took additional study in Mathematics from the University of South Carolina and from South Carolina State University in Orangeburg. She has been an instructor of Computer Science at South Carolina State University since 1990. Prior to that, Davis was Assistant Professor of Computer Information Science and an Instructor of Computer Science at Morris College and Benedict College, respectively. Her work, A Case Study of Urban Heat Islands in the Carolinas, was published in the Journal of Environmental Hazards in 2007. Davis is a Recording Secretary with Kappa Mu Epsilon Mathematics Honor Society, and a Member of the Association of Computing Machinery (ACM). 


\title{
Computational Thinking in K-12 Schools Using Hands-on Activities
}

\begin{abstract}
Recent reports have shown that there is a lack of interest in computer science in the K-12 level and number of incoming college freshmen specifying Computer Science (CS) as an area of study has dropped $60 \%$ over the last 4 years. The educators and administrators are challenged to find ways to engage and promote success and retention of students while maintaining standards in introductory computer science courses. One way to do this is through education and awareness about computational thinking in K-12 curriculum. There are a number of initiatives on this and one such initiative is the STARS (Students \& Technology in Academia, Research \& Service) Student Leadership Corps (SLC). STARS SLC is a NSF funded initiative at University of North Carolina at Charlotte with the primary objective of broadening participation in computing through best practices and community building. SC State is a participating university in this initiative. The objective of this paper is to discuss the STARS SLC outreach and other activities at SC State, its success and lessons learned with the engineering, science, and computing community.
\end{abstract}

\section{Introduction}

It is common knowledge that computing education lacks diversity and enrollments in computer science have plummeted. Recent reports have shown that there is a lack of interest in computer science in the K12 level and number of incoming college freshmen specifying Computer Science (CS) as an area of study has dropped $60 \%$ over the last 4 years. Technology companies are facing a common challenge: finding a diverse, well-trained workforce. Enrollment of minorities and women in computer science in the United States is well below other ethnic and gender groups when compared to their percentages in the general population. Enrollment trends tracked by organizations like the National Center for Women and Information Technology, the Anita Borg Institute for Women and Technology and The Association for Computing Machinery (ACM) all report similar stories ${ }^{1,2,3}$. There is a steady decline in the number of university students graduating with Computer Science degrees over of the last ten years. More alarming is that enrollment and graduation rates in Computer Science are much lower for women and underrepresented minority students.

Computing is becoming part and parcel of every industry, and industries need a trained workforce to manage this new development. Engineering and technology graduates must have a comprehensive background covering a wider range of technical subjects. The graduates must be proficient in the use of computers, engineering and scientific equipment, conducting experiments, collecting data, and effectively presenting the results $4,5,6,7$. In addition to having a good training in their respective disciplines, all graduates must be well-trained in courses and laboratories dealing with computer programming; computer aided design; computer organization and architecture; and others.

Unfortunately, most of the graduates do not perform well in required introductory computing courses due to lack of preparation and interest in STEM subjects, especially computing in K-12 levels. Educators 
are challenged to find ways to address this problem.

The STARS (Students \& Technology in Academia, Research \& Service) Student Leadership Corps (SLC), STARS SLC (http://www.starsalliance.org/leadershipCorps.html), a NSF funded initiative at University of North Carolina at Charlotte, is designed to aid the educators in addressing this challenge. The primary objective of STARS SLC is broadening participation in computing through best practices and community building, and there is an alliance of more than 40 academic institutions of higher learning, called STARS Alliance (http://www.starsalliance.org/participants.html), that are involved in these objectives. The STARS Alliance is open to students and faculty of computing disciplines in these institutions. The objectives of the STARS SLC, as stated in its website, are the following:

The STARS Leadership Corps (Corps) is a multi-year experience providing students with support throughout their academic journey. The Corps fosters an extended student community among academia, industry, and the community through civic engagement, mentoring, and professional development and/or research experiences to promote recruitment and leadership development through service learning. The Corps is implemented with the following central values found to be effective for recruiting and graduating under-represented students in computing.

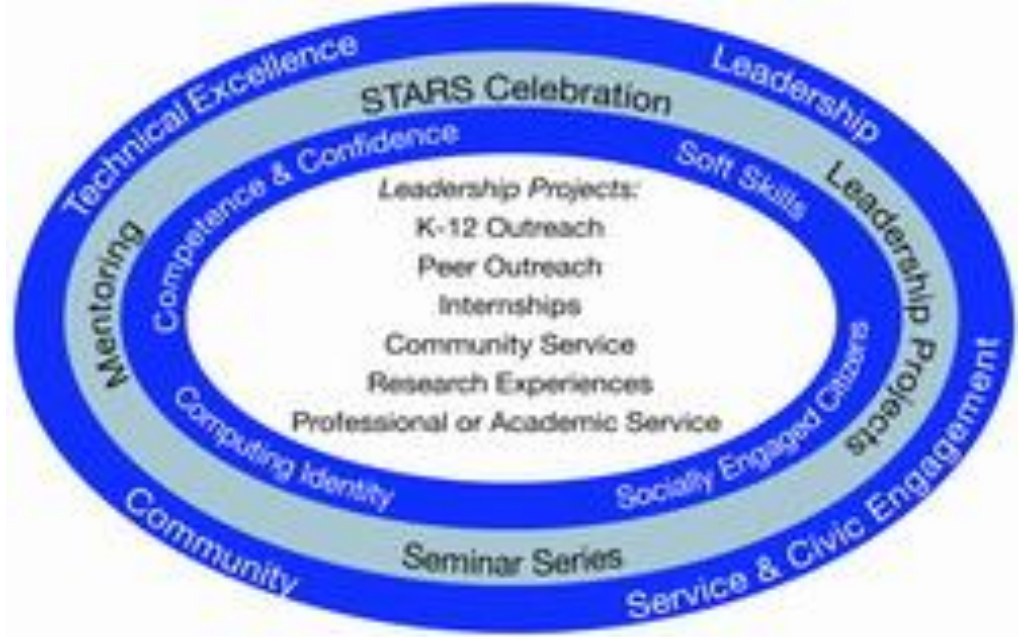

Figure 1 - Corps Model from (http://www.starsalliance.org/leadershipCorps.html)

SC State University is a participating university in this initiative. SC State's STARS SLC is designed to increase awareness about computational thinking in K-12 schools through hands on activities such as designing effective presentations, web design, robotics exercises, algorithmic thinking through the use of Flowchart software Raptor and number systems games. The hope is that these activities will enhance participation of women, under-represented minorities, and persons with disabilities in computing discipline and hence mission of STARS Alliance. SC State's STARS SLC aims to encourage and inform students at all levels on the various computing careers that are available to them. The following are some of the details of our SLC: 


\section{SLC Participation \& Organization}

The SLC at SC State consists of 10 computer science students and 3 computer science faculty. We meet twice a month to plan various outreach and professional development activities. The students work in groups under the supervision of a faculty mentor. They prepare the K-12 outreach lesson plans and deliver the lessons to the participating K-12 school students. The STARS SLC provided nominal funding for students and faculty.

\section{Community Building \& Computing Identity}

This is the second year of SC State SLC and we have managed to reach about 150 elementary/middle school students in two schools (Marshall Elementary School and Felton Laboratory School) during Fall 2011 and Spring 2012. We have started an after school robotics club at Felton Laboratory School, and we have involved one parent in this after school robotics club. We are looking at the possibility of starting one after school robotics club at Marshall Elementary School. We have also started A+ training for undergraduate students at SC State.

\section{SLC Outreach Events/Activities}

The outreach events/activities of SC State SLC are:

- Computational thinking through PowerPoint, EXCEL, robotics programming using Mindstorm NXT at the Marshall Elementary School.

- After school robotics club activities using Java, LabVIEW and MIndStrom NXT at Felton Laboratory School.

- Grant writing collaborations with Felton Laboratory School for grant proposal to $21^{\text {st }}$ Century Grant Program.

\section{Examples of Robotics Activities $\left(3^{\text {rd }}, 4^{\text {th }}\right.$ and $5^{\text {th }}$ graders $)$}

\section{Example 1 - Assembling the Lego Robot}

In this example students are given different parts of Lego Robots and a sketch depicting the type of assembly. Students are divided into teams and each team is asked to complete the assembly. Each team is supervised and assisted by our SLC members. Figure 2 depicts SLC leader explaining the students about this activity and Figure 3 depicts student participation in this activity. 


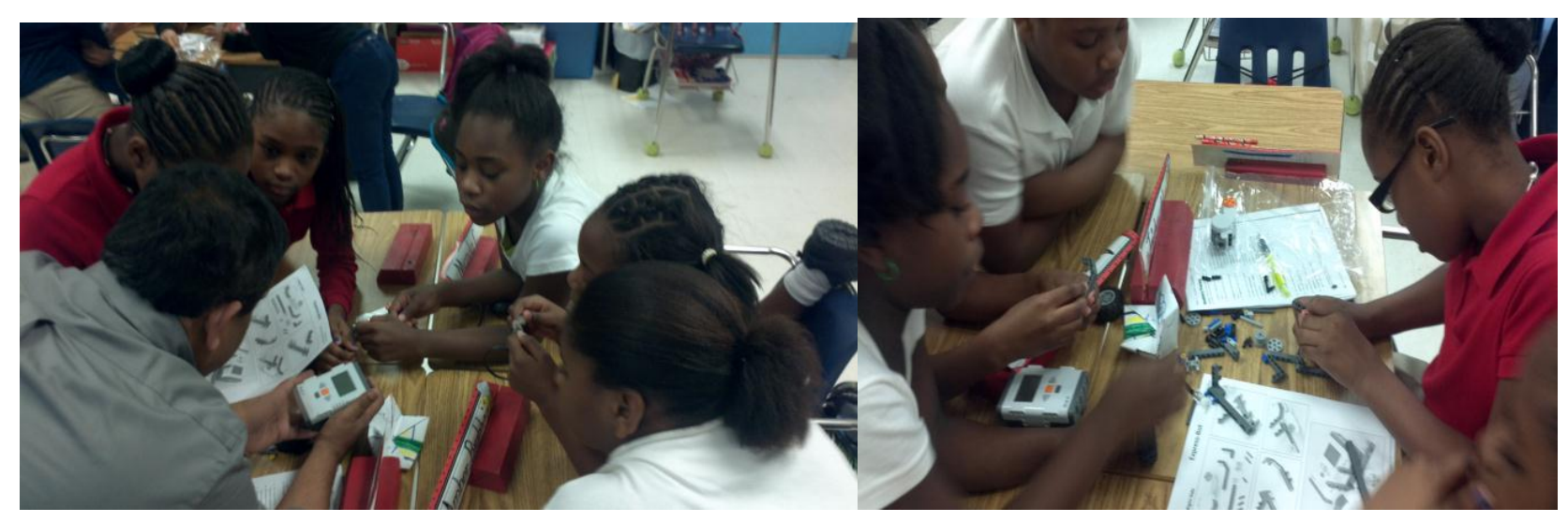

Figure 2-SLC Leader explaining the students

Figure 3 - Students Assembling the Lego Robot

\section{Example 2 - Programming the Lego Robot}

\section{Bumper Car}

This robot has a bumper in front that triggers a touch sensor to tell the robot when it has run into something. The program will make the robot drive around the room, turning each time it bumps into something. Students are asked to assemble and program the robot to accomplish this task. Figure 4 shows the assembly and programming of this activity

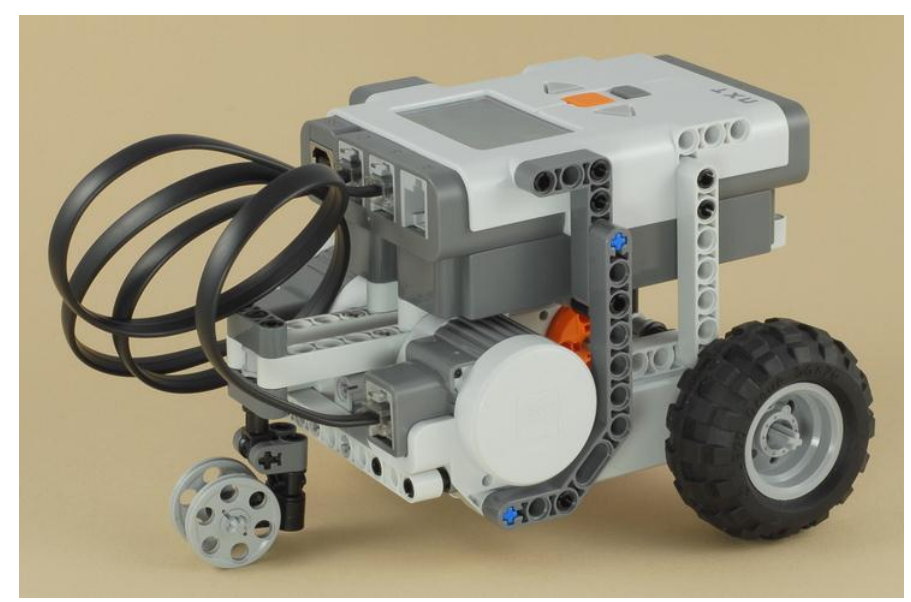


The whole program is contained in a "Forever" loop, so that it will repeat the driving sequence over and over again.

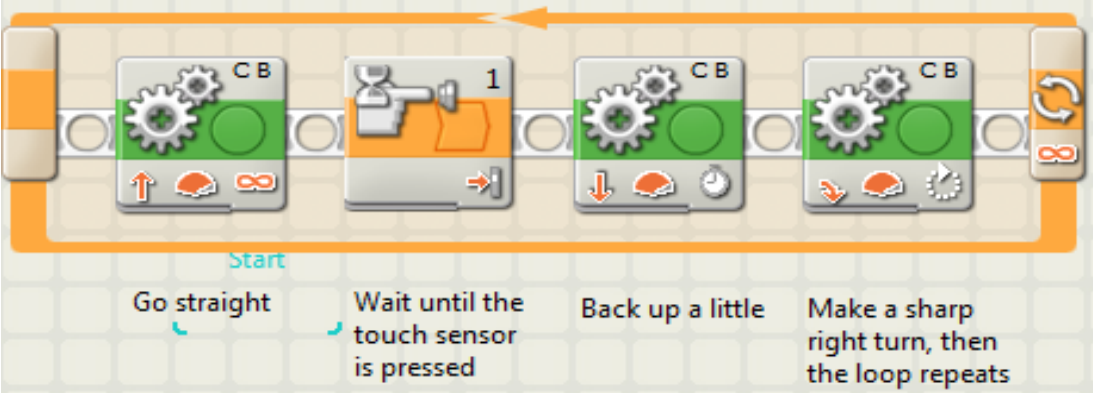

When making the turn, Degrees is used for the Duration so that the turns will be fairly consistent regardless of how strong the batteries are. However, when backing up after hitting something, Seconds is used for the duration, so that the motors will not stall out in case the bumper gets snagged on something. It will try to back up a little, but not keep trying if it is stuck (stalled), then go on to the turn, which will have a chance of breaking away from the snag.

Figure 4 - Bumper car activity

\section{Example 3 - Door Alarm Activity}

In this activity students are asked to assemble the robot and program the robot. The assembly and programming is shown in Figure 5. Figure 6 shows SLC leader explaining the students about the activity. Figures 7 and 8 show student participation.

\section{$\underline{\text { Door Alarm }}$}
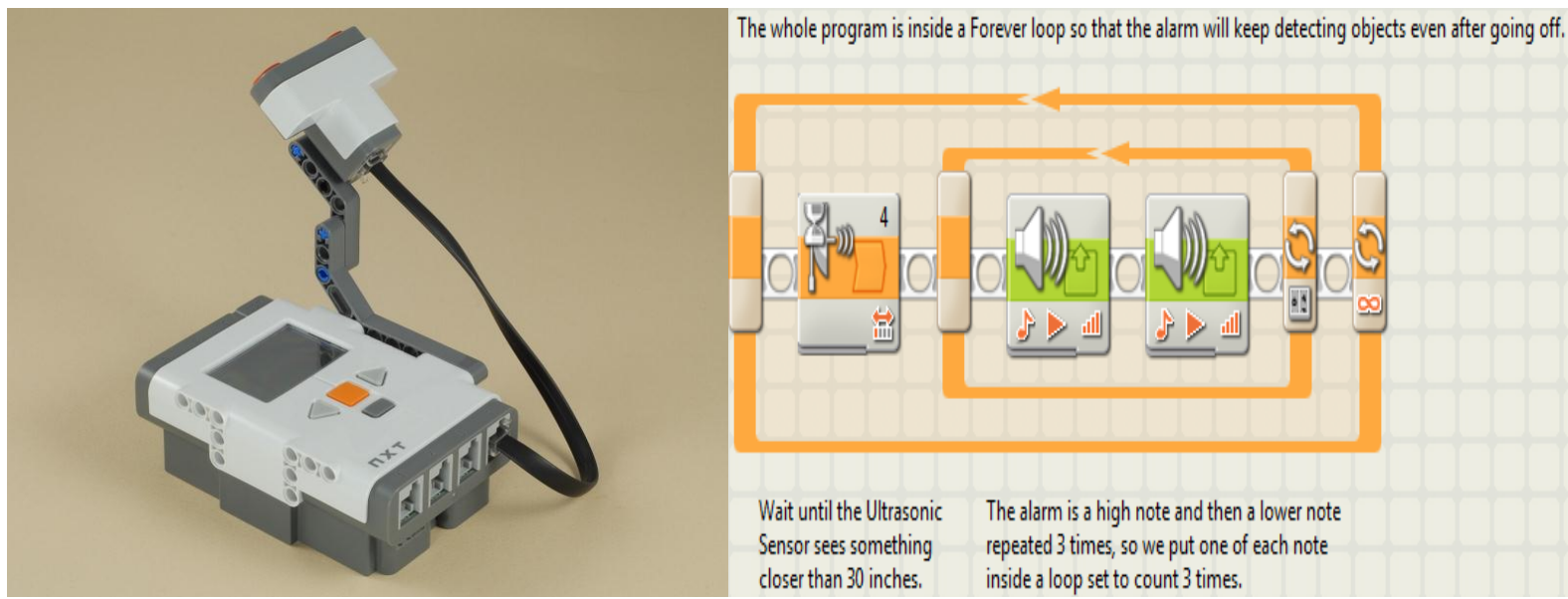

Figure 5 - Door Alarm Activity 


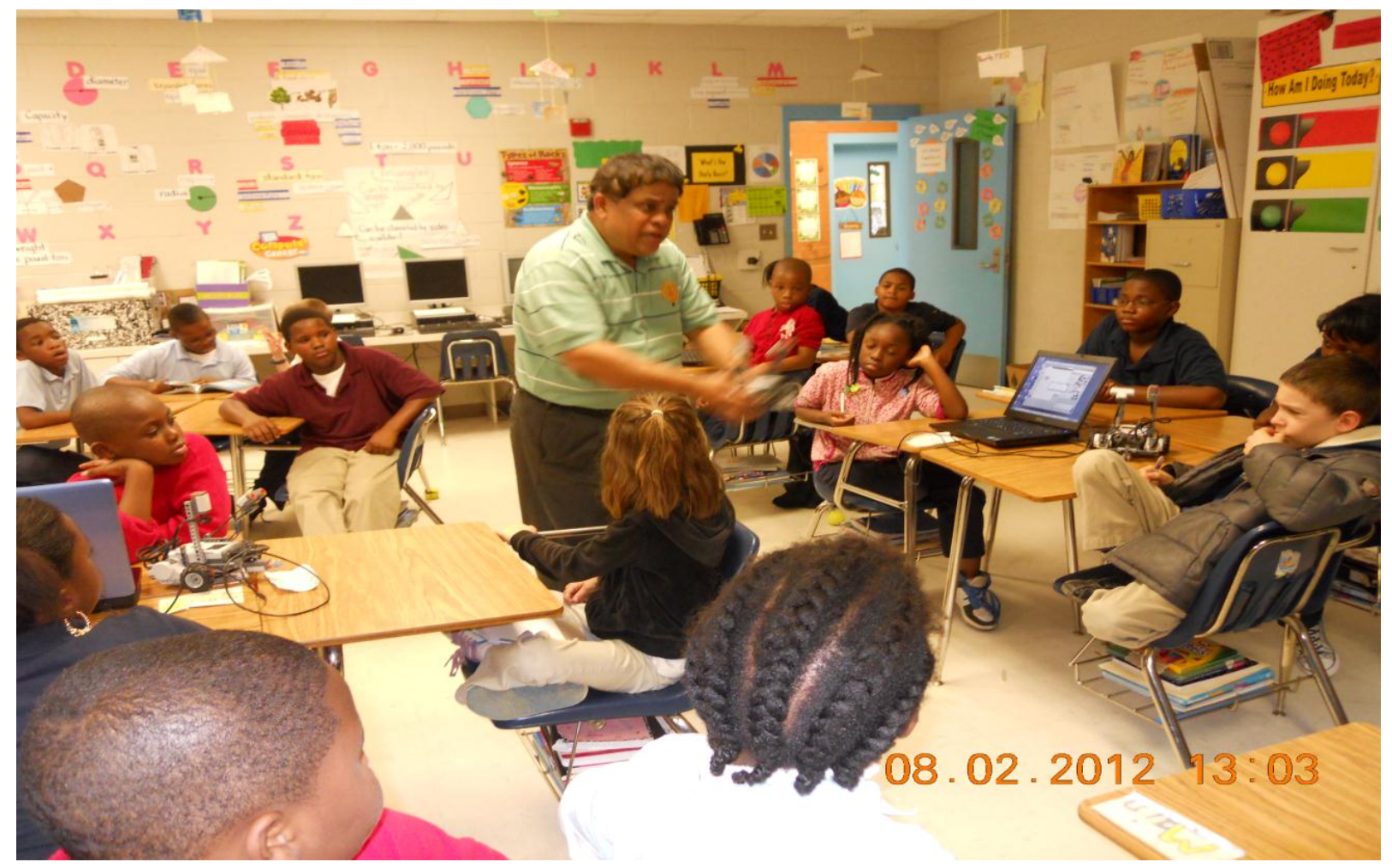

Figure 6 - Explaining the students about the activity

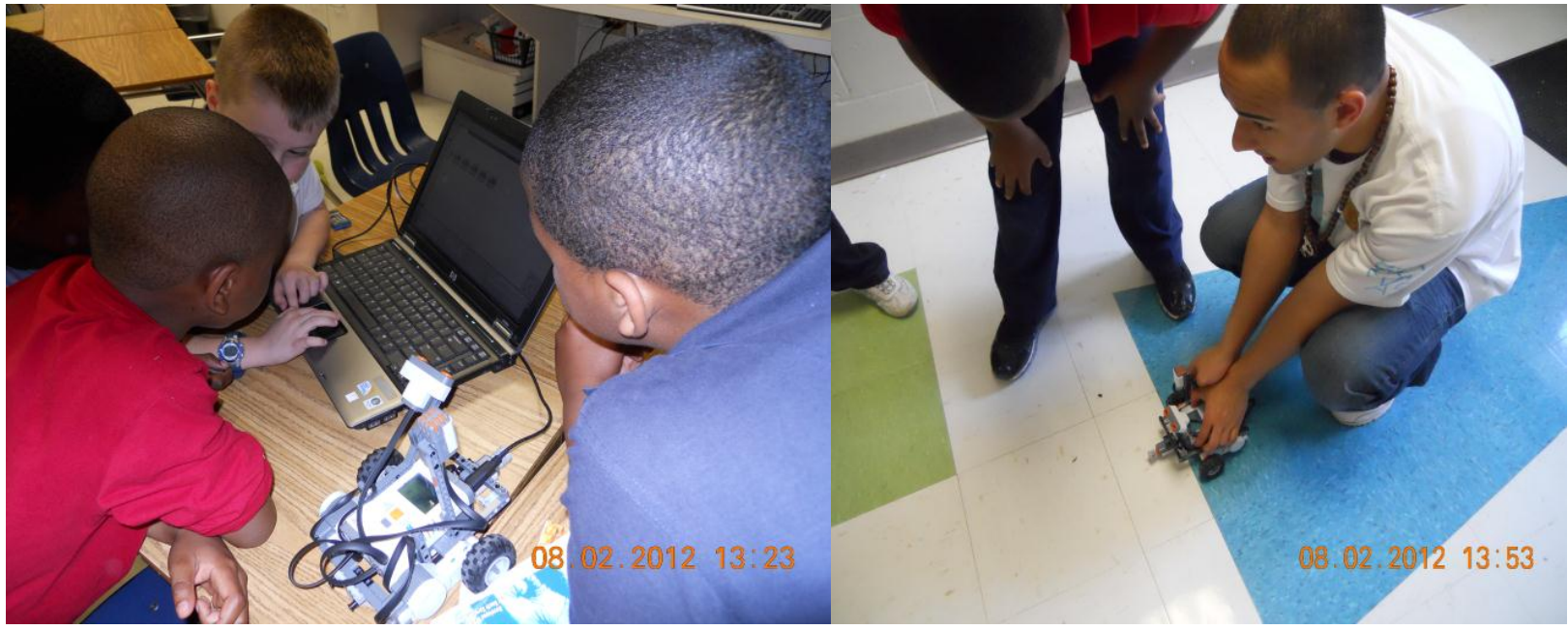

Figure 7 - Student participation (Door Alarm)

Figure 8 - Student Participation (Bumper Car) 


\section{Examples of EXCEL Activities $\left(3^{\text {rd }}, 4^{\text {th }}\right.$ and $5^{\text {th }}$ graders)}

\section{Example 4 - Gradebook Exercise}

\section{Activity Description}

Many school systems have begun to provide grade recording software applications to their teachers. Some instructors prefer to make their own grade book using Excel.

An image of a partially completed gradebook shown below is provided to the students. The SLC leaders explain the students various features and requirements. Students are asked to complete the gradebook and compare their solution with the given solution.

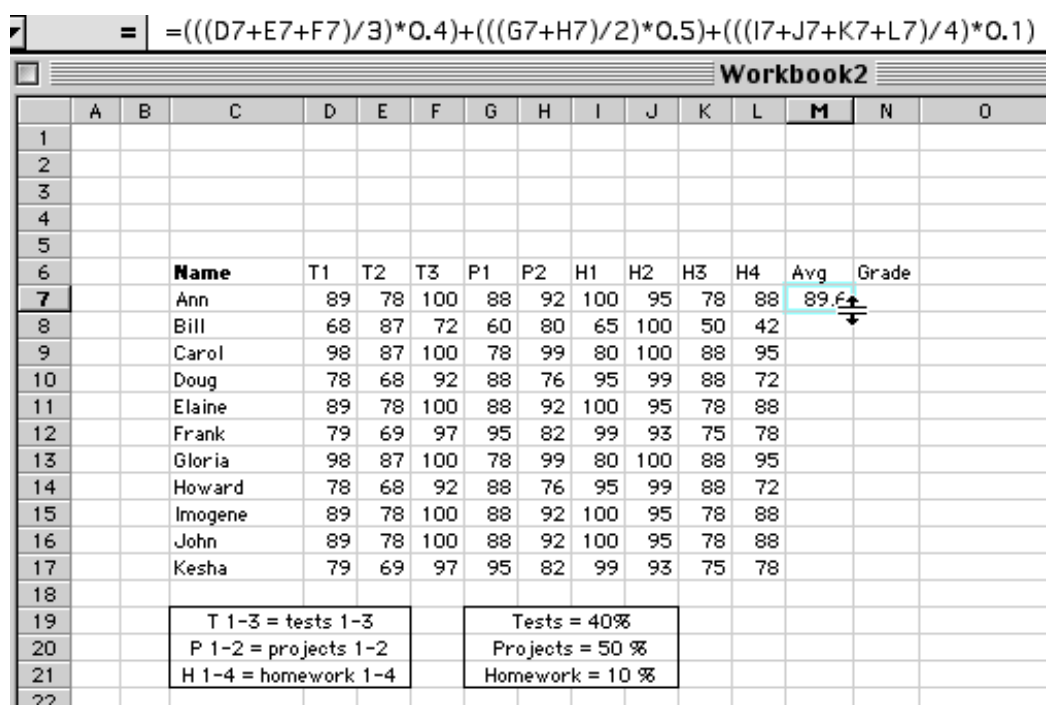

\section{Example 5 - Group Graphing}

\section{Activity Description}

Third grade students were asked to list their favorite sports. The list was compiled by the SLC leader and the results were shared with the students. Students were then asked to present the results in a graphical format using EXCEL. The resulting graph is shown below. The activity is shown in Figure 9.

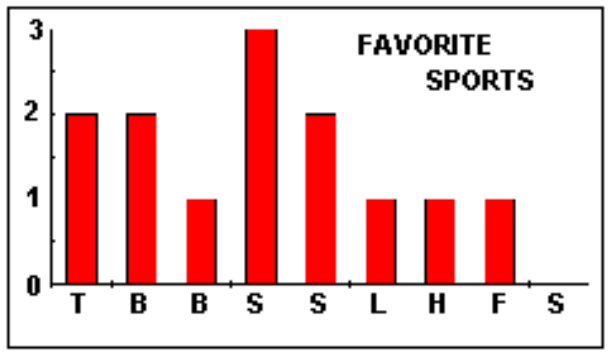




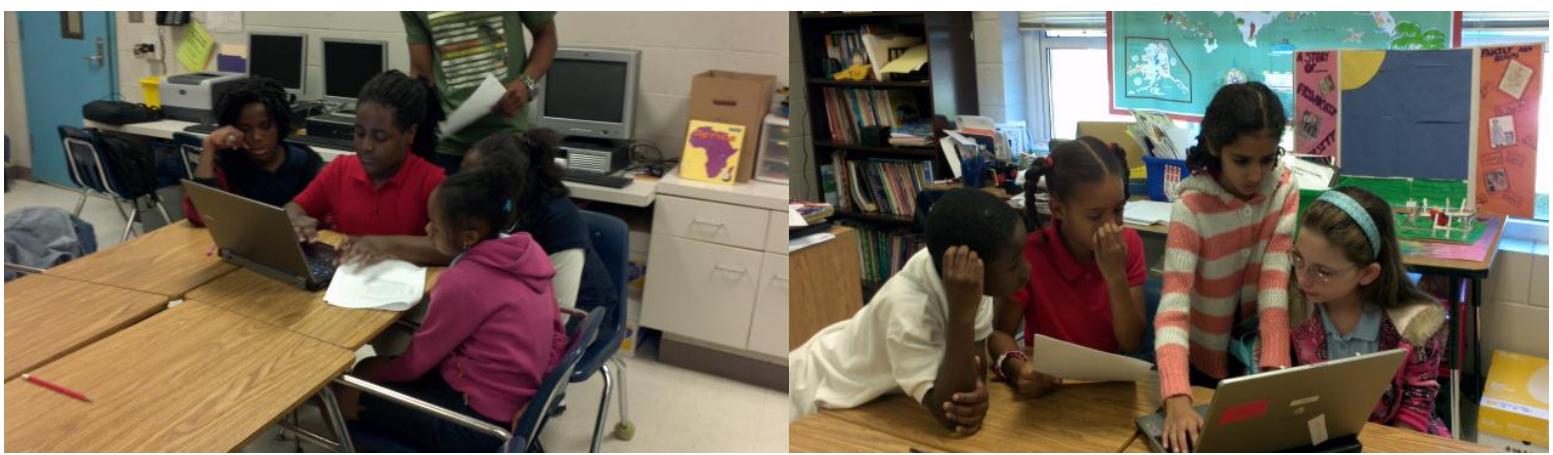

Figure 9 - Pictures of student participation in these activities

\section{Summary of SLC Outreach Activities and Participation}

Summary of our SLC activities is shown in Table 1.

Table 1

\begin{tabular}{|c|c|c|c|c|c|c|}
\hline & & mary audience attendee $i$ & rmation & & & \\
\hline $\begin{array}{c}\text { Outreach } \\
\text { Activity \& } \\
\text { Descriptio } \\
\text { n } \\
\text { (including } \\
\text { CSDT } \\
\text { used) }\end{array}$ & $\#$ & $\begin{array}{c}\text { Primary audience - } \\
\text { Grade level or role (e.g. } \\
7^{\text {th }} \text { grade, middle, high, } \\
\text { parent, teacher, } \\
\text { counselor) }\end{array}$ & $\begin{array}{c}\text { Ethnicity } \\
\text { and } \\
\text { gender }\end{array}$ & $\begin{array}{c}\text {. } \\
\text { \# and } \\
\text { frequency }\end{array}$ & $\begin{array}{l}\text { Duration of } \\
\text { one visit }\end{array}$ & $\begin{array}{c}\text { Total contact hours with } \\
\text { each attendee }\end{array}$ \\
\hline $\begin{array}{l}\text { Computing } \\
\text { class- } \\
\text { Introductio } \\
\text { n to MS } \\
\text { EXECL } \\
5 \text { stars } \\
\text { students } 1 \\
\text { faculty }\end{array}$ & 22 & $5^{\text {th }}$ grade & $\begin{array}{c}50 \% \\
\text { Female } \\
60 \% \\
\text { African } \\
\text { American } \\
30 \% \\
\text { Caucasian } \\
10 \% \text { Asian }\end{array}$ & 1 & $3 \mathrm{hrs}$ & $3 \mathrm{hrs}$ \\
\hline $\begin{array}{l}\text { Computing } \\
\text { class- } \\
\text { Introductio } \\
\text { n to MS } \\
\text { EXCEL } \\
3 \text { stars } \\
\text { students } 1\end{array}$ & 22 & $5^{\text {th }}$ grade & $\begin{array}{c}50 \% \\
\text { Female } \\
60 \% \\
\text { African } \\
\text { American } \\
30 \%\end{array}$ & 1 & $3 \mathrm{hrs}$ & $3 \mathrm{hrs}$ \\
\hline
\end{tabular}




\begin{tabular}{|c|c|c|c|c|c|c|}
\hline faculty & & & $\begin{array}{l}\text { Caucasian } \\
10 \% \text { Asian }\end{array}$ & & & \\
\hline $\begin{array}{l}\text { Computing } \\
\text { class- } \\
\text { Introductio } \\
\mathrm{n} \text { to } \\
\text { Programmi } \\
\text { ng using } \\
\text { MindStrom } \\
\text { NXT and } \\
\text { Lego } \\
\text { Robots } \\
5 \text { stars } \\
\text { students } 2 \\
\text { faculty }\end{array}$ & 22 & $5^{\text {th }}$ grade & $\begin{array}{c} \\
60 \% \\
\text { Female } \\
60 \% \\
\text { African } \\
\text { American } \\
30 \% \\
\text { Caucasian } \\
10 \% \text { Asian }\end{array}$ & 1 & $4 \mathrm{hrs}$ & $4 \mathrm{hrs}$ \\
\hline $\begin{array}{l}\text { Computing } \\
\text { class- } \\
\text { Introductio } \\
\text { n to } \\
\text { Programmi } \\
\text { ng using } \\
\text { MindStrom } \\
\text { NXT and } \\
\text { Lego } \\
\text { Robots } \\
5 \text { stars } \\
\text { students } 2 \\
\text { faculty }\end{array}$ & 22 & $4^{\text {th }}$ grade & $\begin{array}{c}50 \% \\
\text { Female } \\
\\
60 \% \\
\text { African } \\
\text { American } \\
\\
30 \% \\
\text { Caucasian } \\
10 \% \text { Asian }\end{array}$ & 1 & $4 \mathrm{hrs}$ & $4 \mathrm{hrs}$ \\
\hline $\begin{array}{l}\text { Computing } \\
\text { class- } \\
\text { Introductio } \\
\mathrm{n} \text { to } \\
\text { Programmi } \\
\text { ng using } \\
\text { MindStrom } \\
\text { NXT and } \\
\text { Lego } \\
\text { Robots } \\
5 \text { stars } \\
\text { students } 2 \\
\text { faculty }\end{array}$ & 22 & 3rd grade & $\begin{array}{c}50 \% \\
\text { Female } \\
\\
60 \% \\
\text { African } \\
\text { American } \\
30 \% \\
\text { Caucasian } \\
10 \% \text { Asian }\end{array}$ & 1 & $4 \mathrm{hrs}$ & $4 \mathrm{hrs}$ \\
\hline
\end{tabular}




\begin{tabular}{|c|c|c|c|c|c|c|}
\hline $\begin{array}{l}\text { Computing } \\
\text { class- } \\
\text { Introductio } \\
\mathrm{n} \text { to } \\
\text { Programmi } \\
\text { ng using } \\
\text { Java, } \\
\text { LabVIEW, } \\
\text { MindStrom } \\
\text { NXT and } \\
\text { Lego } \\
\text { Robots } \\
5 \text { stars } \\
\text { students, } 1 \\
\text { faculty }\end{array}$ & 20 & $\begin{array}{l}\text { After Hour Robotics Club. } \\
3^{\text {rd }}, 4^{\text {th }}, 5^{\text {th }} \text { and } 6^{\text {th }} \text { grades. }\end{array}$ & $\begin{array}{c} \\
\\
\\
\\
35 \% \\
\text { Female } \\
100 \% \\
\text { African } \\
\text { American }\end{array}$ & $\begin{array}{c}2 \text { times a } \\
\text { week. } \\
\text { Total } \\
\text { visits = } 15\end{array}$ & . & 22.5 hours \\
\hline $\begin{array}{l}\text { First } \\
\text { Robotics - } \\
\text { participatio } \\
\mathrm{n} \text { in } \\
\text { recruiting }\end{array}$ & 40 & $\begin{array}{l}\text { First Robotics \& Spring } \\
\text { Open House }\end{array}$ & $\begin{array}{c}50 \% \\
\text { African } \\
\text { American, } \\
25 \% \\
\text { Hispanic, } \\
25 \% \\
\text { Caucasian }\end{array}$ & 3 & $6 \mathrm{hrs}$ & $6 \mathrm{hrs}$ \\
\hline $\begin{array}{l}\text { Monthly } \\
\text { Planning } \\
\text { Meetings } \\
\text { (Twice a } \\
\text { month) }\end{array}$ & 10 & Within the group & $\begin{array}{c}80 \% \\
\text { African } \\
\text { Americans, } \\
10 \% \\
\text { Caucasian, } \\
\text { and } 10 \% \\
\text { Hispanic }\end{array}$ & 2 & $3 \mathrm{hrs}$ & $3 \mathrm{hrs}$ \\
\hline Totals & & & & & 28.5 & 49.5 \\
\hline
\end{tabular}

\section{Conclusion and Impact of SLC Activities}

The computational thinking activities have been received very well by the students, faculty and staff at these schools and we have been requested to increase the frequency of our visits. These schools have helped us with letter of support for the outreach components of our grant proposals to external agencies. We have also helped in these schools in their grant writing efforts and currently our SLC is providing Felton Laboratory School with 4 hours/week after hour computational thinking (robotics, algorithmic thinking, MS Office and others) activities as a part of our commitment to their $21^{\text {st }}$ century grant. We think we have made a difference. In the words of one mother "My son wants to be a robotics scientist/engineer after participating in the robotics activities by SC State SLC students". 


\section{Acknowledgement}

This work was partly funded in part by a grant from the STARS Alliance. We are thankful to the STARS Alliance for providing us with this help.

\section{References}

1. DuBow, W. (2011). NCWIT Scorecard: A report on the status of women in information technology. Boulder: NCWIT.

2. Simard, C., (2009). Obstacles and Solutions for Underrepresented Minorities in Technology www.anitaborg.org/news/research.

3. Gürer, D., Camp, T., (2010). Investigating the Incredible Shrinking Pipeline for Women in Computer Science (Final Report - NSF Project 9812016)

http://women.acm.org/archives/documents/finalreport.pdf.

4. Swain, N. K., Korrapati, R., Anderson, J. A. (1999) "Revitalizing Undergraduate Engineering, Technology, and Science Education Through Virtual Instrumentation”, NI Week Conference, Austin, TX..

5. Elaine L., Mack, Lynn G. (2001), "Developing and Implementing an Integrated Problem-based Engineering Technology Curriculum in an American Technical College System" Community College Journal of Research and Practice, Vol. 25, No. 5-6, pp. 425-439.

6. Buniyamin, N, Mohamad, Z., 2000 "Engineering Curriculum Development: Balancing Employer Needs and National Interest--A Case Study" - Retrieved from ERIC database.

7. Kellie, Andrew C., And Others. (1984), "Experience with Computer-Assisted Instruction in Engineering Technology”, Engineering Education, Vol. 74, No. 8, pp712-715. 